\title{
The Ecology of First Language Acquisition Nativism and Empiricism: An Appraisal and a Compromise
}

\author{
Ali Asghar Kargar \\ English Department, Islamic Azad University, Abadeh Branch, Iran \\ Email: Kargar928@Gmail.com
}

\begin{abstract}
Contrary to the common belief that nativism and empiricism are two distinct theories of first language acquisition, both have some contribution to our understanding of the process of language acquisition; however, Neither of them is able to provide testable accounts of the details of language acquisition. As a result, Emergentism is proposed as an alternative with a wider scope to cover more of the realities about language acquisition. According to this paradigm, "formal structures of language emerge from the interaction of social patterns, patterns implicit in the input, and pressures arising from the biology of the cognitive system" (MacWhiney, 1998, P. 200). In this paper, it is attempted to match the picture of the first language acquisition with the metaphor of "the ecology of language" proposed by Brown (2000) for second language acquisition. The picture shows that genetic, physiological, cognitive, developmental and environmental factors before and after birth are at work, and language acquisition, in fact, is the consequence of interactions among all these factors.
\end{abstract}

Index Terms - first language acquisition, empiricism, nativism, emergentism

\section{INTRODUCTION}

Language acquisition is one of the most intriguing aspects of human development. It seems that it is a tremendous task to find an answer to the question of how a language is acquired. How do children accomplish language acquisition? What pushes them to go on developing complex grammatical languages? What factors inside and outside the child help this remarkable development happen? One of the most critical theoretical issues is whether the knowledge the child acquires is innately specified or is learned through environmental interaction (Tartter, 1998). The first view is held by the nativists, while the second one refers to the empricists'. Nativists believe that children are born with an innate predisposition to acquire language without which language acquisition would be unfeasible. Empricists, on the other hand, assign the crucial role to environmental input. In most cases, the two theories are perceived as two opposite views about the same phenomenon, though both have some contribution to uncovering the mysteries of language acquisition. To make a compromise between these two broad theories of FLA, the researcher has borrowed the idea of "the ecology of language acquisition" (fig.1) from Brown (2000, P.295). He uses the idea to elaborate on how different factors, innate and environmental, are involved in second language acquisition. He extends a "seed-flower" metaphor to the language acquisition. He says that language acquisition develops like "a flower seed whose genetic makeup predisposes it to deliver, in successive stages, roots, stem, branches, leaves and flowers"; simultaneously, "the rain clouds of input stimulate seeds of predisposition" (P. 294). Hence, if FLA is a natural phenomenon, using a metaphor from the nature may help reveal the relative value of the host of factors contributing to the acquisition of language, although the amount of correspondence remains controversial. To accomplish this, first the idea will be presented in pictorial form (fig. 2); then nativists' as well as four empricists' theories including statistical learning, chunking, social interactionism and relational frame theories will be matched with different parts of the picture. Finally, emergentism will be presented as a compromise between nativism and empiricism. 


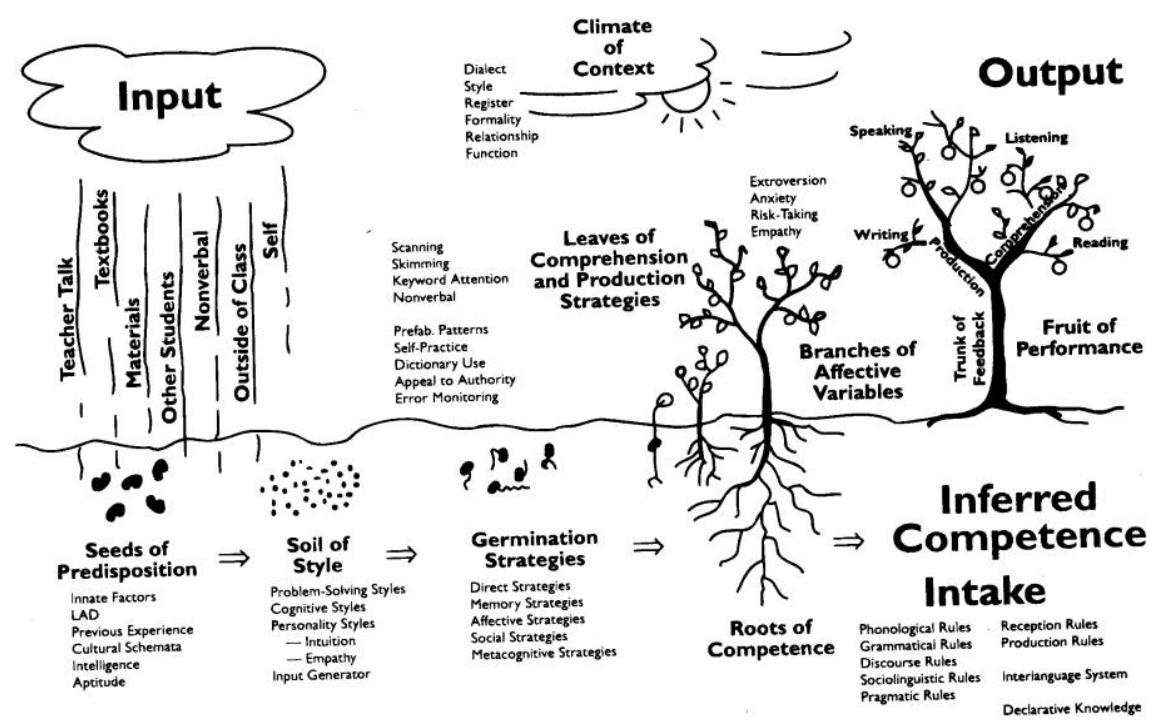

Figure1. Ecology of second language acquisition (Brown, 2000)

The Ecology of FLA

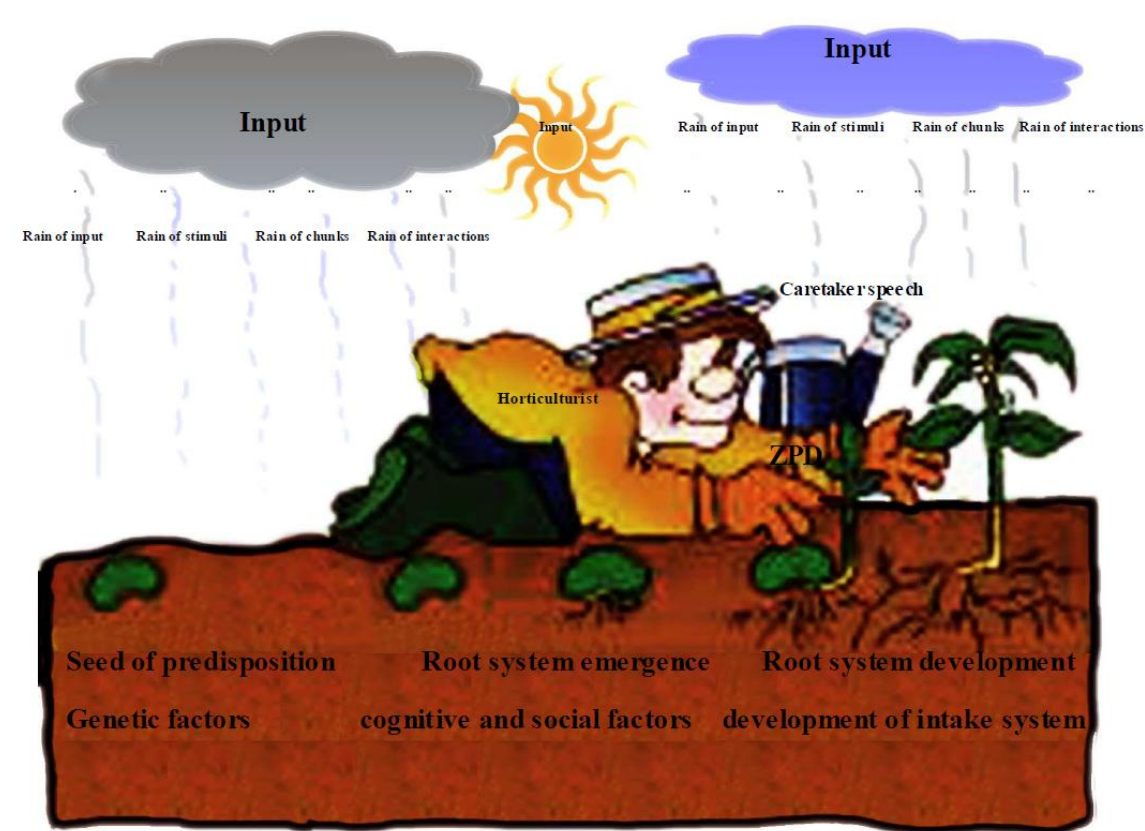

Figure2. The ecology of first language acquisition: language emergence and development are the result of innate and environmental factors.

\section{NATIVIST'S VIEW}

Nativists believe that language is a part of human genome, and "language acquisition is innately determined" (Brown, 2000, P.24). Chomsky asserts that from a Martian's eye-view all humans speak a single language, implying that the same symbol-manipulating machinery underlies the human languages. In Chomsky's words;

'The facts are known without experience, and they need not be taught to a person learning Spanish or English.... . Evidently, the facts come to be known on the basis of biological endowment that is prior to any experience and that enters into determining the meaning of words with remarkable precision and surely not in any way that is logically necessary.' (Chomsky, 1980, p. 28)

Chomsky believed that the child is exposed to a language in the environment full of confusing information such as false starts, incomplete sentences or slips of tongue, so it cannot provide all the information which the child needs (Lightbown \& Spada, 2000). The idea was discussed by innatists as the "poverty of stimulus". They concluded that children are by no means systematically connected or instructed on language. They claim that not only are parents inconsistent in their correction, but also they do not correct some of the children's errors. Moreover, even if they correct errors, children often ignore the corrections, continue to use their own ways of saying things. Chomsky (1969 cited in 
Brown, 2000) proposes that children are able to learn language because they are equipped with a language acquisition device (LAD). Only small language samples from the environment serve as a "trigger" to activate the device. When it is activated, the child is able to discover the structure of the language by matching the innate knowledge to the structure of the particular language in the environment.

Following Chomsky, White (1989) argued that without Universal Grammar, it would not be possible for a child to acquire language. The child needs to be constrained from incorrect hypotheses, but these constraints are not provided by the input data. They must be part of the child's biologically determined endowment. This supposition is nurtured by the idea that the language the child is exposed to is disorganized, ungrammatical and confusing. Furthermore, Chomsky (1969) argued that it would be a simplistic view to think of children as coming to language with a blank mind and then being conditioned to it through parental and social approval. Rather, there must be a very considerable innate disposition to language.

Chomsky argues his inateness hypothesis on basically three accounts: firstly, the existence of language universals. It is argued that the similarity in languages cannot possibly be due to anything other than a specific cognitive capacity in man. The universals of language to which Chomsky refers to are of two types: formal universals referring to the way language works and substantive universals, the categories which language uses.

The second count on which Chomsky argues his innateness hypothesis is the fact of language learning. He argues that the adult speech which a child hears around him is so poorly structured and impaired in performance (by hesitation, repetition, false start and so on) that he could not possibly learn language unless he brought to the task a very specific capacity. In particular, a child must be pre-tuned to some of the formal universals by which language operates. The learning theory states that events in the child's environment shape language behavior. The verbal behavior, like any other behavior, is acquired and maintained by the consequences it generates. The environment clearly plays a role in language acquisition. When talking to young children, parents and other adults use a kind of language that is dubbed as child directed speech (motherese). Characteristics of motherese include higher pitched voice, greater pitch variations, slower rate of speech, shorter, simpler sentences, simple and concrete words, clearer articulation, repetitive speech, and exaggerated facial expression. Language development requires social interaction and a nurturing environment. However, beyond motherese, children seldom receive consistent modeling of and reinforcement for their language behavior. Young children typically encounter fragmented and incomplete utterances and a variety of reactions (annoyance, approval, rejection, ignoring, etc.) to their utterance. Studies show that children are reinforced for truth-value of their utterances and not for grammatical accuracy, yet children master grammar. Ironically, children grow up to speak grammatically but not always truthfully!

The existence of the mother-to-child code which appears simpler than adult-adult speech is often considered evidence for the influence of environmental variation on children's language acquisition (Feldman \& Shen, 1971). A conclusion to be drawn is that while the motherese evidence is suggestive, it does not demonstrate environmental effects on language acquisition.

The third count of Chomsky's argument concerns the speed of acquisition of language. Language could not be learnt with the speed it is unless the child were programmed to do so. The amazing speed with which children acquire their first language is said to substantiate an innate ability in them to learn language. In Chomsky's (1988, P.28) words;

"The child, equipped with the endowed innate language faculty, observes people around them using the language, the set of expressions in the language which the child hears- and the contexts in which they are used-in the course of acquiring language constitute the child's linguistic experience of the language. This experience serves as input to the Child's language faculty."

Furthermore, Lenneberg (1967) proposes that language is "species specific" behavior, and its mechanisms are biologically determined. In other words, the fact that only human beings are able to develop language can obviously be attributable to language genes operating in all humans as the result of evolution (Rutter, 2006). According to Lenneberg (1967), the appearance of language primarily depends on the maturational development of states of readiness within the child. Correspondingly, all children learn language in spite of environmental differences and in some cases deprivations. In other words, poor language environment does not prevent child language acquisition.

Some nativist theoreticians even go that far to hold language as a human instinct (Pinker, 1994). In their view, language is considered a distinct piece of the biological makeup of the brain. It grows on humans as an organ like ear grows on the head. Rutter (2006) referring to the studies on some specific developmental disorders of language called Specific Language Impairment (SLI) (e.g. Viding et al.'s 2004) concludes that such disorders (SLI) have substantial heritability. SLI symptom is marked delay in language comprehension, production and social communicative aspects of language development in children with normal physical and psychological development.

In line with nativists' expectations, Anthony Monaco of the University of Oxford, England, leading a genetic aspect of a study, found that a gene called FOXP2, located on chromosome 7 is associated with language (Trivedi, 2001). They found that a family identified as "KE" family, were unable to select and produce the fine movements with tongue and lips necessary to speak clearly. Moreover, members of the family had dyslexic tendencies as well as difficulty processing sentences and poor spelling and grammar.

In the metaphor of the flower seed, the role genes play is to determine the emergence of different parts of the plant. The genetic predisposition cannot be seen directly, but it has the crucial role in the growth of the flower. It controls the 
development of different parts of the plant. Brown (2000), in his illustration of "the ecology of language" for SLA refers to the seeds of predisposition consisting of "innate factors, LAD, previous experience, cultural schemata, intelligence, and aptitude" (p.295). However, in our illustration for FLA, the flower seed refers to the idea proposed by nativists that language is first "species specific" possessed only by humans, and the fact that language development starts by biological impetus led by language genes, though they have not been fully identified yet. Without language genes or the seed of language no growth is possible. This is what Chomsky calls LAD or UG; however, due to the abstractness of his ideas, while genes are objectively and scientifically proven, it is very difficult to relate them together.

\section{EMPIRICISTS’ VIEW}

While nativists try to find what happens under the ground before and at the time of the growing of the language, empiricists look above the ground to see how it blossoms. Relational Frame theory is a good example. It has been developed largely through the efforts of Steven C. Hayes and Dermot Barnes-Holmes and currently being tested in about three dozen laboratories around the world. Its focus is on how humans learn language through interactions with the environment (Hayes, Barnes-Holmes \& Roche, 2000). The theory rejects the nativists' view as:

"We don't need the idea of a language device any more than we need a "walk device," a "watch TV device," or a "play it off and try to look cool when you stumble because you really meant to do that device." (Blackledge, 2003, P.425)

Consequently, RFT like behaviorism focuses on language experience and its value in process of language acquisition, although unlike behaviorism it distinguishes human being from other creatures for his extraordinary cognitive ability to distinguish and create relations, as key concepts in RFT, among stimuli (Blackledge, 2003). In other words, humans are able to respond to relations among stimuli as well as responding to each stimulus separately. As the theory suggests, language acquisition is the result of the interaction between stimuli and the organism. Matching the idea and our illustration, we can say that the plant of language grows as result of absorbing water and other minerals by its roots. The root system is able to distinguish and absorb input and send it to other parts of the plant. According to such theories, abundant input like spring rain makes the flower seed grow and blossom.

Another theory which emphasizes the crucial role of input is statistical learning theory. According to the theory, infants are able to detect phonetic distributions using statistical information of input (Peperkamp, Le Calvez, Nadal \& Dupoux, 2006). Based on the frequency and order of occurrence of certain sounds and syllabi in the language being exposed to, infants are able to form hypotheses about the phonology of the language. The same mechanism can be used to track grammatical structures (Endress \& Mehler, 2009; Johnson \& Riezler, 2002). Although this theory like RFT considers human cognition as the center of processing input, they both see input itself as the crucial factor for the growth. RFT calls it stimuli, where as in statistical learning theory, infants use the statistical information of input to acquire the language. Applying it to the illustration we depicted, we can conclude that it can also magnify the way root system distinguishes and absorbs water and minerals for the plant to grow.

According to their definition in Wikipedia Encyclopedia, chunking theories also assume that the input from the environment plays an essential role. They are based on the idea that language development is the result of "incremental acquisition of chunks" of language including phonemes, syllables, words and sentences. Clark (1974) argues that "routines or chunks do evolve into patterns which in turn become creative language... child's speech becomes creative through the gradual analysis of the internal structure of sequences which begin as prepackaged routines" (p. 9). In this paradigm, even meaningless pattern practice may provide some input for the creative construction to process. Similarly, acquiring lexical phrases is easy, since they are highly frequent chunks that can be associated with their contexts (Huang \& Hatch, 1978). Finally, chunks lead to a degree of automaticity to take over in both comprehension and production. Like other empiricist theories, chunking theories can be pasted to our picture. It also emphasizes the role of the rain of input. Rain of language chunks can be considered as a main factor in growing the flower of language. The root system functions as the processor of the chunks of water, minerals and other nutrients.

The next empiricist theory which seems to have something new to add to our picture is social interactionism first proposed by Lev Vigotsky. Interactionists attribute more importance to the environment (Lightbown \&Spada, 2000). They emphasize the role of the child directed speech which is adjusted in ways that make it easier for them to understand the language. It is believed that children develop their language through interaction and conversation with adults and other children. Van Der Veer (1986 cited in Ghassemzadh, 2005) distinguishes the child's environment from the animal environment in that "human environment is a social environment, that the child is part of a living environment". Many researchers have studied child-directed speech, the language which adults use with their children. It is believed that the language adults use when talking with children is a modified language with certain characteristics. Lightbown and Spada (2000) state that in English the language adults use when talking with children involves "a slower rate of delivery, higher pitch, more varied intonation, shorter, simpler sentence patterns, frequent repetition, and paraphrase" (p.24). In addition, topics of conversations are usually limited to the "child's immediate environment" or what the child is aware of. According to Lightbown and Spada (2000), what is important to children is the interaction they have with more proficient speakers intuitively adjusting the language to their level of understanding rather than mere simplification or modification. 
The zone of proximal development (ZPD) is considered Vygotsky's "most important psychological methodological discovery" (Newman and Holzman, 2005, P.52). Vygotsky (1987 cited in Newman and Holzman, 2005, P.53) defines it as,

The state of development is never defined only by what has matured. If the gardener decides only to evaluate the mature or harvested fruits of the apple tree, he cannot determine the state of his orchard. Maturing trees must also be taken into consideration. The psychologist must not limit his analysis to functions that have matured. He must consider those that are in the process of maturing. If he is to fully evaluate the state of the child's development, the psychologist must consider not only the actual level of development but the zone of proximal development.

The central point in the definition as Newman and Holzman (2005) pointed is the "relationship between 'matured' and 'maturing' processes. In fact, it refers to what the child can do independently and in collaboration with others. A child can accomplish more with collaboration, help or support than he can alone. However, Vygostsky believes that the child's potential is not unlimited even if he is helped (Newman \& Holzman, 2005, P.54). As a good example for this, they refer to the idea of child's imitation,

For example, the view that imitation is a purely mechanical process and that therefore the child is capable of imitating virtually anything was, according to Vygotsky, incorrect. The child —and the rest of us, for that matter-can only imitate what is in the range of our developmental level (the ZPD): 'If I am not able to play chess, I will not be able to play a match even if a chess master shows me how'. Studies of early language acquisition conducted in the 1970s gave further empirical weight to Vygotsky's argument. It was found that individual children not only vary in the amount they imitate the language they hear, but they are selective in what they imitate, i.e. children do not imitate what they know well nor what is far beyond their linguistic level.

Vygotsky (1982 cited in Daniels, 2003, P.48) explains the zone of proximal development as follows,

The child is able to copy a series of actions which surpass his or her own capacities, but only within limits. By means of copying, the child is able to perform much better when together with and guided by adults than when left alone, and can do so with understanding and independently. The difference between the level of solved tasks that can be performed with adult guidance and help and the level of independently solved tasks is the zone of proximal development.

Lantolf (2000) reminds us that "the ZPD is not a physical place situated in time and space; rather it is a metaphor for observing and understanding how meditational means are appropriated and internalized"(P. 16). According to this author, what someone can achieve with support from others and/or cultural artifacts is different from what he/she can achieve when acting alone. However, it is not the matter of simple copying of the behavior rather the children "transform what the experts offer them as they appropriate it". The key to this transformation is "imitation, which along with collaboration in the ZPD" is the cause of human development (Lantolf, 2000, P.18). Here imitation is considered more complex than pure copying, and it is believed to involve communicative activities. The following conversation is a good example for the effectiveness of imitation in ZPD framework:

Child: (opening cover of a tape recorder) open, open, open

Adult: Did you open it?

Child: (watching tape recorder) open it

Adult: Did you open the tape recorder?

Child: (watching tape recorder) tape recorder

(Newman and Holzman 1993, cited in Lantolf, 2000, P.18)

As the result of the imitation of adult's utterances, the child has been able to produce something new (open $\rightarrow$ open it $\rightarrow$ tape recorder). Based on the concept of ZPD, development occurs only if the child needs an optimum level of help; when the task is not too difficult or too easy for the child to do (Ellis \& Barkhuizen, 2005).

On the other hand, according to Ellis and Barkhuizen (2005) having the same actual level of development does not guarantee the same potential level of development. It means two children may have different levels of potential level of development and consequently a different rate of development based on how well they respond to the help provided by others.

In our metaphor, social interactionism adds the role of horticulturist as a person who waters with sprinkler, adds fertilizers, cuts the extra branches and helps the plant grow. This type of input really works in agriculture, and so does in language acquisition.

\section{MERGing THE THeORIES}

The metaphor used to depict language acquisition proved that neither nativism nor empiricism can present a complete picture of the process. The comprehensive picture can only be achieved from merging all the theories. Each theory only reveals the partial fact about language acquisition. Merging the theories of both sides can show the overall picture. Both nativistm and empiricism have some contributions in revealing the mysteries of language acquisition. Meanwhile, both have the pitfall of exaggerating the effect of either genetic or environmental factors.

Emergentism, as MacWhinney (2002) proposes, allows us to consider "new ways of dealing with age-old confrontation between nativism and empiricism" (p.4). He puts that,

Emergentism does not imply a radical rejection of either nativism or empiricism. On the contrary, emergentism views nativist and empiricist formulations as the partial and preliminary components of a more complete account. The 
traditional contrast betweennativism and empiricism revolves around the fact that they describe developmental processes that operate across different timeframes.

He adds that everything in human development is the result of "some unspecified interaction between nature and nurture" (P.4). In other words, Emergentism tries to remove the opposition by proposing that language acquisition is the result of an interaction between biological and environmental factors. It seems that it fits our metaphor and can explain the illustration more comprehensively.

MacWhiney (2002) asserts that there are many examples for emergence in the nature. One example is the outline of the beaches resulting from the interactions between geology and ocean current. Another example is weather patterns like Jet Stream or EL Nino emerging from the interaction of factors like the rotation of the earth, solar radiation, and the shape of the ocean bodies. He says that biological phenomena have similar patterns. The shapes of the spots on a leopard or the stripes on a tiger are other good examples (Murray, 1988 cited in MacWhinney, 2002). They emerge due to operating color related genes across the developing leopard or tiger embryo. Contrary to the nativists' belief, no single gene directly controls the pattern. Instead, they emerge from the interactions of the genes on the physical surface of the embryo. Correspondingly, the emergence of the language is the result of interaction of the host of genetic and environmental factors. It is too simplistic to think that there is only one single gene responsible for language. Our naturalistic metaphor can also depict how all these factors including genetic and environmental interact to grow the flower seed of language. In fact, emergentism can best explain the metaphor of "the ecology of FLA".

Bates and MacWhinney (1988) say that language is a "new machine built out of old parts" (p. 147). It refers to the fact that old theories are not descriptively adequate to show complete picture of language acquisition. They say that old parts include features like physiology and perception, processing and working memory, pragmatic and social interaction, input and the learning mechanisms.

Emergentism is similar to nativism in that both believe that the brain is innately structured and that there are some language related genes. However, it opposes "representational nativism" meaning there are direct innate grammatical principles and parameters as proposed by UG (Elman et al. 1996, P.369). In addition, it rejects that there are specific language or grammar genes. Considering the case of KE family and FOXP2, they assert that the family members also had problems with swallowing, finger tapping, mouth control and other fine actions. This pattern of impairment, as Pinker (1991) concluded, showed that FOXP2 is neither the "gene of language" nor "the gene of grammar".

Contemporary emergentism also makes use of the empiricists' frameworks to explain linguistic development. They believe that there are learning mechanisms like inductive generalizations that help extract statistical regularities from experience in forms of associations and memorized chunks (Ellis, 2002), or computational routines (O'Grady, 2005). Emergentism rejects the idea of "poverty of stimulus" proposed by Chomsky and asserts that input is crucial especially for the acquisition of vocabulary (Tomasello, 1986).

However, emergentism does not reject nativism and empiricism completely and tries to make a compromise between their formulations as the partial components of a more complete paradigm. According to MacWhinney (2005), the traditional contrast between nativism and empiricism originates from description of developmental processes that operate across different timeframes. He distinguishes seven separate timeframes for emergent processes and structures:

1) Evolutionary or Phylogenetic Emergence: These emergent structures are those that are encoded in the genes affected by natural selection.

2) Epigenetic Emergence: It refers to the translation of the DNA in the embryo, triggering a further set of processes from which the initial shape of the organism emerges.

3) Developmental Emergence: It consists of the basic learning process that involves the continual learning of new facts, forms, relations, names and procedures as well as learning of new strategies and frameworks that can alter the overall shape of language and cognition, often through cue focusing.

4) Online or Processing Emergence: It indicates how language structure emerges from the pressures and loads imposed by online processing including social processes, memory mechanisms, attentional focusing, and motor control.

5) Diachronic Emergence: It shows the changes that languages have undergone across the centuries, emerging from the interaction of the previous three levels of emergence (evolutionary, developmental, and online).

6) Social Emergence: As the result of long-term social commitments, we learn to choose appropriate vocabulary, slang, topics to emphasize solidarity, impose our power, or seek favors.

7) Interactional Emergence: It refers to short-term commitments to ongoing social interactions.

Each timeframe explains how language acquisition might be affected by the nature or the environment. In other words, it suggests that the process can be more under the influence of one factor regarding the time of its emergence. In first and second timeframes, language acquisition is more governed by the nature, but in later timeframes its role is gradually blurred, and in sixth and seventh timeframes seems to reach it minimum level.

To sum up, language acquisition is a natural phenomenon, and like other natural phenomena is affected by lots of factors including natural and environmental ones. Ecology of first language acquisition can be used to cover both types of factors. To understand what factors are involved in the process of language acquisition, both under and above the surface of the ground should be investigated. Before the flower seed starts to grow, genetic and innate factors determine the route of the growth. In line with emergentism, even genetic domain of language acquisition should be subject to scientific investigation. Clouds of input, experience, parents' talk and interactions then stimulate the growth. This is 
highlighted in timeframes proposed in emergentism as well as interactionists' findings. Roots and leaves of cognitive ability have the ability to absorb and process and use water, minerals and other nutrients. As the root system extends, the plant takes more and grows faster than before. Interaction among internal and external factors increases, and the plant grows more and more. The sixth and the seventh timeframes pinpoints the effects of social interactions. The overall growth of the plant is the result of interaction among genetic endowment, different types of input and absorbing system. Finally, it begins to blossom and flower. Full growth is possible only if the plant is protected, watered and pruned by a skilled horticulturist.

\section{CONCLUSION}

Neither nativism nor empiricism is able to provide testable accounts of the details of language acquisition; however, both of them shed some light to our understanding of its process. Emergentism, as a result, was devised as an alternative with wider scope to cover more of the realities about language acquisition. At the same time, it rejects the empricists' negligence of genetic factors as well nativists' approach to make vague stipulations about hidden part of language acquisition. According to this newer paradigm, "formal structures of language emerge from the interaction of social patterns, patterns implicit in the input, and pressures arising from the biology of the cognitive system" (MacWhiney, 1998, P. 200). In this paper, it was attempted to match the picture of the first language acquisition with the metaphor of "the ecology of language" proposed by Brown (2000) for second language acquisition. The picture shows that genetic, physiological, cognitive, developmental and environmental factors before and after birth are at work, and language acquisition, in fact, is the consequence of interactions among all these factors.

\section{REFERENCES}

[1] Bates, E. and MacWhinney, B. (1988). "What is Functionalism?" Papers and Reports on Child Language Development. 27, 137-52.

[2] Blackledge, J. (2003). An introduction to Relational Frame Theory: basics and applications. The Behavior Analyst Today, 3 (4). 421-433

[3] Brown, H.D. (2000). Principles of Language Learning and Teaching. (4th eddition).New Jersey: Prentice Hall, Inc.

[4] Chomsky, N. (1969). 'Linguistics and philosophy'. In S. Hook (Eds.), Language and Philosophy (pp.125-144). New York: New York University Press.

[5] Chomsky, N. (1980). 'On cognitive structures and their development. In M. Piattelli-almarini. Language and Learning: the Debate between Jean Piaget and Noam Chomsky (pp.18-56). London: Routledge Kegan Paul.

[6] Chomsky, N. (1988). Language and Problems of Knowledge: The Managua Lectures. Cambridge, MA: MIT Press.

[7] Clark, R. (1974). Performing without competence. Journal of child language, 1, 1-10.

[8] Daniels, H. C. (2003). An Introduction to Vygotsky. NY: Routledge Publications.

[9] Ellis, N. (2002). "Frequency Effects in Language Processing." Studies in Second Language Acquisition. 24, 143-88.

[10] Ellis and Barkhuizen G. (2005). Analysing Learner Language. Oxford: Oxford University Press.

[11] Elman, J., Bates, E., Johnson, M., Karmiloff-Smith, A., Parisi, D. and Plunkett, P. (1996). Rethinking Innateness. A Connectionist Perspective on Development. Cambridge, MA: MIT Press.

[12] Endress, A. D., and Mehler, J. (2009). The surprising power of statistical learning: When fragment knowledge leads to false memories of unheard words. Journal of Memory and Language. 60, 351-367.

[13] Feldman, C. \& Shen, M. (1971). Some language-related cognitive advantages of bilingual five-year-olds. Genetic Psych. 118, 235-244.

[14] Gasemzadeh, H. (2005). Vygotsky's Mediational Psychology: a New Conceptual of Culture, Signification and Metaphor. Language Science. 27, 281-300.

[15] Huang, J. and Hatch, E. (1978). A Chinese child acquisition of English. In E. Hatch, Second language acquisition: A book of readings (pp.201-238). Rowley, MA: Newbury House.

[16] Hayes, S., Barnes-Holmes, and Roche (2000). Relational frame theory: a post Skinnerian account of human language and cognition. New York: Kluwer Academic Plenum Publishers.

[17] Johnson, M., Riezler, S. (2002). Statistical models of syntax learning and use. Cognitive Science. 26, $239-253$.

[18] Lantolf, J. P. (2000). Sociocultural Theory and Second Language Learning. Oxford: Oxford University Press

[19] Lenneberg, E. (1967). Biological foundations of language. New York: John Wiley.

[20] Lightbown, P, M. and Spada, N. (2000). How languages are learned. Oxford: Oxford University Press.

[21] MacWhinney, B. (1998). "Models of the Emergence of Language." Annual Review of Psychology. 49, 199-227.

[22] MacWhinney, B. (2002). Language Emergence: An Integrated View of Language Development. Trier: Wissenshaftliche Verlag

[23] MacWhinney, B. (2005). The emergence of linguistic form in time. Connection Science, 17( 3-4) , 191-211

[24] Newman, F. and Holtzman, L. (2005). Lev Vygotsky: Revolutionary Scientist. NY: Routledge Publications.

[25] O’Grady,W. (2005). Syntactic Carpentry: An Emergentist Approach to Syntax. Mahwah, NJ: Erlbaum.

[26] Peperkamp, S., Le Calvez, R., Nadal, J. and Dupoux, E. (2006).The acquisition of allophonic rules: Statistical learning with linguistic constraints. Cognition. 101, 31-41

[27] Pinker, S. (1991). Rules of language. Science. 253, 530-535.

[28] Pinker, S. (1994). The Language Instinct. New York: William Morrow and Company, Inc.

[29] Rutter, M. (2006). Genes and behavior: Nature-Nurture Interplay Explained. MA: Blackwell Publishing Ltd.

[30] Tartter, V. C. (1998). Language and its normal processing. London: Sage Publications.

[31] Tomasello, M. (1986). Joint attention and early language. Child Development. 57, 1454-1463.

[32] Trivedi, B. P. (2001). Scientists Identify a Language Gene. Retrieved from www. National Geographic.com/news in June, 2010. 
[33] Viding, E., Spinath, F., Price, T.S., Bishop, D.V.M., Dale, P.S., \& Plomin, R. (2004). Genetic and environmental influence on language impairment in 4-year old same sex and opposite-sex twins. Journal of Child Psychology and Psychiatry, 45, 315-325.

[34] White, L. (1989). Universal Grammar and Second Language Acquisition. Amesterdam, Philadelphia: John Benjamin.

Ali Asghar Kargar is a PHD student in TEFL at Shiraz University, Iran. He has been a lecturer in the Department of English at Islamic Azad University, Abadeh branch. He has been teaching different courses in TEFL and English Translation for 10 years. His research interest includes teaching and testing language skills especially reading and writing as well as teaching methodolog y. He has also published a book in essay writing entitled "easy essay". 